\title{
Naturally Occurring Egg Drop Syndrome Infection in Turkeys
}

\author{
Z. BIĐIN ${ }^{1}$, I. LOJKIĆ ${ }^{1}$, M. MIKEC ${ }^{2}$, B. POKRIĆ ${ }^{3}$ \\ ${ }^{1}$ Department of Poultry Diseases, Faculty of Veterinary Medicine, University of Zagreb, Croatia \\ ${ }^{2}$ Poultry Centre, Croatian Veterinary Institute, Zagreb, Croatia \\ ${ }^{3}$ Ruđer Bošković Institute, Zagreb, Croatia \\ Received February 12, 2007 \\ Accepted July 9, 2007 \\ Abstract
}

Biđin Z., I. Lojkić, M. Mikec, B. Pokrić: Naturally Occurring Egg Drop Syndrome Infection in Turkeys. Acta Vet. Brno 2007, 76: 415-421.

\begin{abstract}
A decrease in the egg quality, production, fertility and hatchability without serious clinical signs of illness was recorded in turkey flocks in Croatia at the beginning of 2002. It was assumed that the egg drop syndrome virus might be one of the etiological agents responsible for the abnormalities in the egg production. The systematic serological monitoring, using a haemagglutination inhibition test, showed that the antibodies to the egg drop syndrome virus existed in 94.4 and $55.1 \%$ of the sera analysed in 2002 and 2003, respectively. The haemagglutination inhibition titres ranged from 16 to 128 . The sera samples were randomly collected from 11 - to 46 -week-old hens from the affected flocks. The serological evidence of the egg drop syndrome virus infection was confirmed by detection of the presence of the virus genome in the turkey sera by the polymerase chain reaction. Vaccination of the 18- and 25-week-old turkey hens against the egg drop syndrome virus started in March 2003. After this period, the presence of antibodies to the egg drop syndrome virus (the haemagglutination inhibition titres between 16 and 256 ) was found in $96.7 \%$ of the analysed sera, while the egg production reached normal or higher values for the Nicholas hybrid line of turkeys.
\end{abstract}

Croatia, egg drop syndrome virus, haemagglutination inhibition, Meleagris gallopavo

Egg drop syndrome (EDS) affecting the flocks of laying fowl was described for the first time in 1976 (Van Eck et al. 1976). The EDS virus (EDSV), an etiological agent of the disease, designated as a duck adenovirus type 1, belonging to Atadenovirus genus (Harrach et al. 1997; Hess et al. 1997; Dán et al. 1998; Benkő et al. 2005), was isolated from the chickens during the 1980s and 1990s worldwide (McFerran and Adair 2003). The EDSV or the antibodies against the virus have been detected not only in hens but also in wild birds (Malkinson and Weisman 1980), wild waterfowl (Schlör 1980; Gulka et al. 1984), and pigeons (Durojaiye et al. 1992). In spite of the fact that the disease outbreaks were recorded only in laying hens, it has been demonstrated that ducks and geese were natural EDSV hosts (Schlör 1980; Zsak et al. 1982; Bartha and Mészáros 1984; Brugh et al. 1984). The receptivity to the infection and its transmission by contact were observed in pheasants, guinea fowls and quails (Zanella et al. 1980). The EDS outbreaks observed in the quail flocks, maintained together with infected chickens, resulted in the fall of the egg production, the increase of the number of the soft-shelled eggs, as well as the development of the HI-antibodies to virus (Das and Pradhan 1992). The involvement of the EDSV in a severe respiratory disease of the young goslings was also reported (Ivanics et al. 2001).

Optimal growth of the EDSV has been observed in the duck cells, but it was poor in the turkey cells. However, the experimental infection confirmed that turkeys can be infected by a direct contact, the eye-drop and the combined intranasal and oral routes (Parsons et al. 1980; Zanella et al. 1980; Kaleta et al. 2003), without any clinical signs of the infection. The virus could be detected in cloacal swabs during the period between 3 and 10 days after

Address for correspondence:

Ivana Lojkić

Department of Poultry Diseases, Faculty of Veterinary Medicine,

University of Zagreb,

Heinzelova 55, 10000 Zagreb

Croatia

Phone: +385-1-2390 281

Fax: +385-1-2390-135

E-mail: ilojkic@vef.hr

http://www.vfu.cz/acta-vet/actavet.htm 
the infection. A rapid humoral response has been generated one week post infection and the detectable antibody titres were found 28 weeks later. In spite of this fact, no data concerning natural infection of the turkey flocks with the EDSV have been reported as yet.

A significant decrease in both egg quality and production was recorded in several turkey flocks in Croatia at the beginning of 2002. The affected flocks were known to have avian pneumovirus (APV) infection, but the abnormalities in the egg production were not recorded prior to the year 2002. At the same time, the turkeys were negative to the avian influenza virus (AIV), Mycoplasma gallisepticum (MG), and Mycoplasma synoviae (MS), while the Newcastle disease virus (NDV) infection was controlled by a systematic vaccination. These facts suggested that the decline in egg production might be caused by some other agent, possibly a naturally-occurring EDSV infection. For this reason, a serological and histopathological monitoring, as well as polymerase chain reaction (PCR) analysis of the sera samples collected from the birds suspected to be infected with the EDSV, were carried out. A differential diagnosis including the APV, NDV, AIV, MS and MG, was performed.

\section{Materials and Methods}

Turkeys

Nicholas hybrid line breeders were placed into production units with about 1100 birds each. During the whole period they were housed on litter in a controlled environmental housing. The birds were fed nutritionally adequate diets and treated according to the producer's recommendations. At the age of 2 weeks, the hens were vaccinated against NDV by oculo/nasal $(\mathrm{o} / \mathrm{n})$ administration of a live vaccine. At the age of 5 weeks, they received a live NDV vaccine by spray. The sixteen-, 18 - and 25 -week-old breeders were boostered intramuscularly $(\mathrm{i} / \mathrm{m})$ with an inactivated NDV oilvaccine. A modified vaccination schedule was applied from March 2003. The eighteen- and 25-week-old hens received $\mathrm{i} / \mathrm{m} 1.0 \mathrm{ml}$ of a two-component oil-vaccine containing inactivated ND and EDS viruses, instead of a one-component inactivated oil-vaccine against the NDV. The egg production was expressed as the average number of the eggs/turkey/ week. Morbidity and mortality were monitored daily. The dead birds were necropsied and the organs were submitted for pathological analysis. The blood samples were taken by brachial vein puncture.

Serological analyses

The seroprevalence of antibodies to EDSV was determined in the sera collected from 30 breeder flocks (322 samples) prior to the vaccination, and 13 breeder flocks ( 151 samples) after the vaccination. The turkeys were between 11 and 46 weeks old. The levels of the antibodies against the EDSV were determined by haemagglutination inhibition test (HI-test). The two-fold serial dilution test was performed with 4 haemagglutination (HA) units of the EDS' 76 strain BC14 and 0.8\% chicken erythrocytes (Adair et al. 1979). The HI-titres $\geq 16$ were considered positive.

The presence of the antibodies against the NDV was determined by the HI-test using a $\beta$-microtitration procedure (Allan and Gough 1974). The HI-tests were performed with a constant volume of $50 \mu \mathrm{l}$ of serially double-diluted sera in multiwell plastic plates with V-shaped wells in the presence of $1 \%$ suspension of the chicken erythrocytes and the 4 HA units NDV La Sota strain as an antigen. The HI-titre of an antiserum corresponds to the highest serum dilution that inhibits haemagglutination. The HI-titres $\geq 16$ were considered positive.

The sera samples were analysed for the antiAPV antibodies using a Flockscreen ${ }^{\text {TM }}$ (Guildhay Ltd, Guildford, England) ELISA kit. Flockscreen ELISA titres $\geq 1210$ were considered positive. The titres $\leq 876$ were considered negative, while the sera titres between 877 and 1209 were in the suspect range.

Antibodies against AIV were determined by immunodiffusion test in $0.8 \%$ agar gel (AGID) supplemented with $0.15 \mathrm{M} \mathrm{NaCl}$ and $0.1 \% \mathrm{NaN}_{3}$ by using the AIV strain A/Shearwater/Australia/70 (H6N5) as an antigen (kindly provided by prof. B. Sinković, Central Veterinary Laboratory, Glenfield, N.S.W. 2167, Australia). The antisera that formed immunoprecipitates with the antigen after 24 -hour incubation at $37^{\circ} \mathrm{C}$ in a wet chamber were considered positive.

The presence of antibodies against Mycoplasmae was detected by a rapid serum agglutination test using the Nobilis ${ }^{\circledR}$ MG strain S6 of Adler and MS strain WVU-1853 antigens (Intervet International B. V., Boxmeer, The Netherlands). The test procedure and the evaluation of the results were given according to the prescriptions of the antigen producer. A blue-coloured flocculation occurring within 2 minutes, characterized a positive reaction. The reaction was considered negative for the fail of agglutination after an observation period of $2 \mathrm{~min}$. The flocculation which occurred after 2 min was considered a doubtful reaction.

PCR analysis for determination of EDSV

Sera samples were collected on 4 breeding farms during the period between 2002 and 2003. A trivalent oilvaccine Nobilis IB+ND+EDS (Intervet, Boxmeer, The Netherlands) containing the EDS'76 strain BC14, was used as a positive control. A haemorrhagic enteritis virus of turkey antigen for agar gel immunodiffusion test (Poultry Centre, Zagreb) was used as negative control. 
From the sera and the vaccine, $200 \mu \mathrm{L}$ was submitted to DNA extraction using a Machery-Nagel Nucleospin ${ }^{\circledR}$ Blood extraction kit (Düren, Germany) according to the manufacturer's instructions. The concentration of the DNA extracted was determined spectrophotometrically at $260 \mathrm{~nm}$.

Primers H5F and H6R specific for the EDSV hexon gene were used according to the data given by Raue and Hess (1998). For PCR, $50 \mathrm{ng}$ of DNA were mixed together with $0.2 \mathrm{mM}$ of each primer in a total volume of $25 \mu \mathrm{L}$ using an AccuPrime ${ }^{\mathrm{TM}}$ Taq DNA Polymerase System (Invitrogen, Carlsbad, CA, USA). The PCR was carried out using a GenAmp PCR System 2400 (Applied Biosystems, Foster City, CA, USA) under the following conditions for 30 cycles, $94{ }^{\circ} \mathrm{C}$ for $45 \mathrm{~s}, 54^{\circ} \mathrm{C}$ for $45 \mathrm{~s}, 68^{\circ} \mathrm{C}$ for $1.5 \mathrm{~min}$. The amount of $10 \mu \mathrm{L}$ of each PCR product was analysed by electrophoresis in a $1 \%$ agarose gel stained with ethidium bromide.

\section{Results and Discussion}

Rough, thin, soft-shelled or irregularly shaped eggs accompanied by a fall in the egg production, were recorded in turkey laying flocks for the first time during the first quarter of 2002. During the period from the $3^{\text {rd }}$ to the $5^{\text {th }}$ week of laying, the drop in the egg production in three flocks varied between 3.7 and 14.5\% (Fig. 1, 2002a). At the same time, a decrease in fertility was observed in 8.7 to $19.0 \%$ of the eggs, while the $1^{\text {st }}$ class hatchability was low in $1 \%$ of the eggs during 5 weeks. The HI-titre values of all the sera collected from 36-week-old hens at the $5^{\text {th }}$ week of lay (Fig. 1, 2002a, denoted by an arrow) were positive to the antiEDSV antibodies and varied between 16 and 64 .

The fall in egg quality and quantity continued in 2002 and at the beginning of 2003 . Two diagrams characteristic for the egg production in 2002 (Fig. 1, 2002a and 2002b) and one for the beginning of 2003 (Fig. 1, 2003a) are presented. The egg shell changes and the reduced egg quality preceded or were concurrent with the decline of the egg production. A total decrease of the hatchability rate amounting to $7.7 \%$ accompanied the drop of the egg production and quality in 2002.

During the period of the decreased egg quantity and quality, 322 sera samples (233 in 2002, and 89 at the beginning of 2003), were analysed for the presence of the antiEDSV antibodies. It was found that 94.4 and $55.1 \%$ of the sera samples collected during 2002 and at the beginning of 2003, respectively, were antiEDSV positive (Fig. 2). The antibody HI-titres ranged from 16 to 128 . The presence of the antiEDSV antibodies was detected in the sera collected at the beginning and during the laying period at the hen age of $30,31,36$, $38,39,43,46$ weeks, as well as prior to the laying period in the sera of 11-, 15-, 21-, 24and 27 -week-old pullets. During the period of a decrease in the egg production, no serious clinical signs of the illness were observed in the birds. Only a few birds showed very mild respiratory difficulties. The food intake was not reduced. No specific pathological changes were found during the histopathological examinations. Mortality was within a normal range for the Nicholas hybrid line.

Hen vaccination against the EDSV began in March 2003. The egg production reverted to the normal values or to the values higher than normal for the Nicholas hybrid line (Fig. 1, $2003 \mathrm{~b}$ ). As a result of the vaccination, $96.7 \%$ of a total of 151 analysed sera were antiEDSV positive (Fig. 2). Higher average values of the antiEDSV antibody levels were generated by a vaccination rather than by a naturally-occurring infection (Fig. 2). The vaccination against the EDSV was carried out using a vaccine dose twice as high as that used for the chickens. We assumed that, for this reason, the naturally-occurring infection resulted in a lower humoral immune response than that elicited by a high EDSV vaccine dose.

The PCR analysis confirmed the presence of the EDSV in the serum sample of a 36week-old antiEDSV positive non-vaccinated hen (Fig. 3, lane 5). The serum sample was collected during the period of the first observation of abnormal eggs (see Fig. 1, 2002a, the arrow). The results of PCR analyses of 7 randomly chosen antiEDSV negative sera samples, collected from 20- to 30-week-old turkey hens during the period of a suspected EDSV infection prior to the vaccination, are presented in lanes $6-12$ (Fig. 3 ). The presence of EDSV was detected in 4 serum samples (lanes 6, 8, 10 and 11). The 

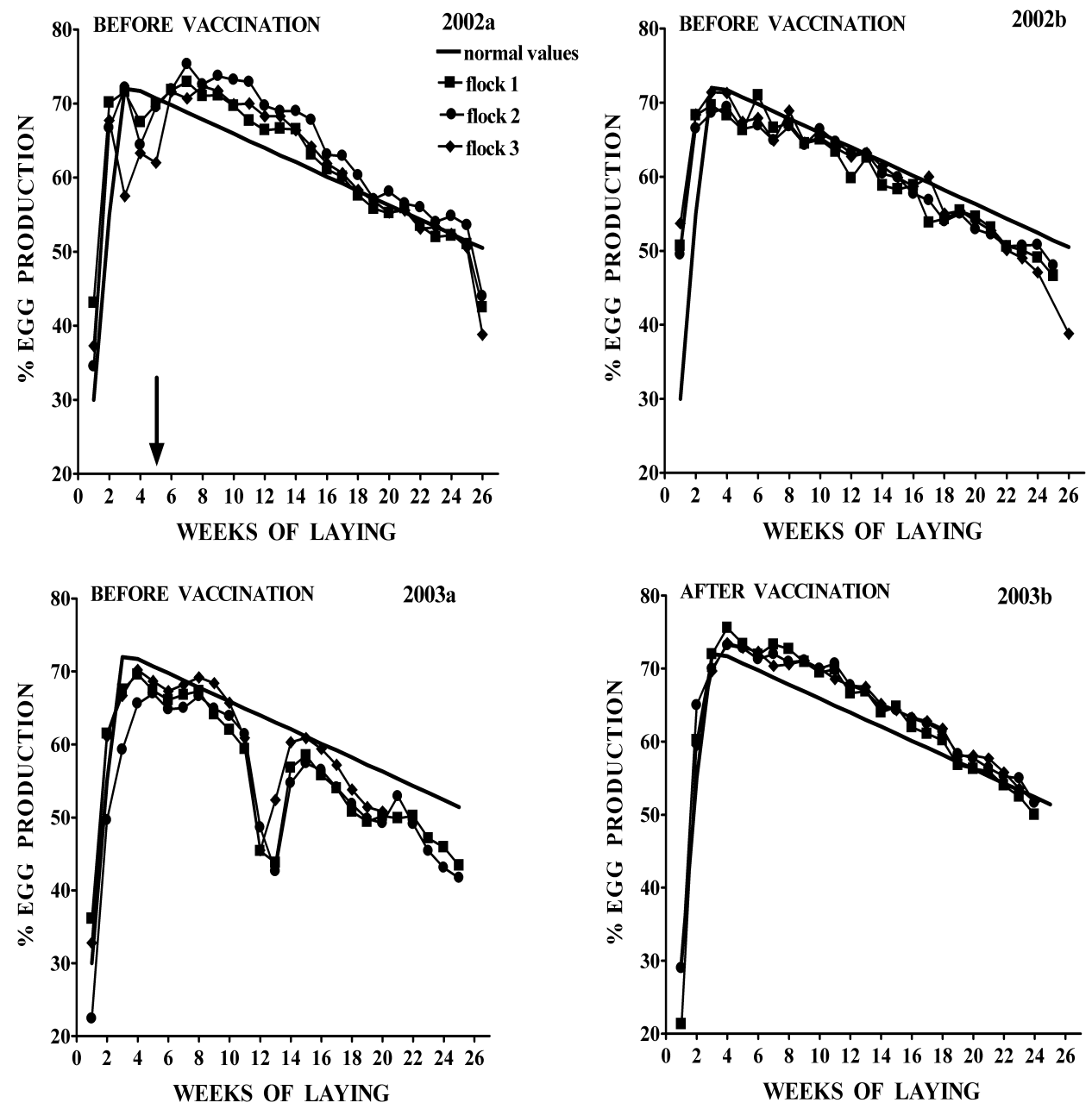

Fig. 1. Egg production curves characteristic for the period prior to (2002a, 2002b, 2003a) and after (2003b) turkey vaccination against EDSV

EDSV was also detected in a serum sample of a hen twice vaccinated against the EDSV (Fig. 3, lane 4).

Primers H5/H6 (Raue and Hess 1998) hybridized in two variable regions (L1 and L4) of the EDS hexon gene where the lowest sequence identities between the EDS and other fowl adenoviruses (FAVs) were found which enable a clear differentiation between these viruses. This was verified by use of a commercially-available EDSV vaccine as positive control, and antigen for HEV detection as negative control for the PCR analysis. The PCR confirmed the presence of the EDSV in the antiEDSV positive sera samples of a non-vaccinated and a vaccinated hen (Fig. 3, lanes 5 and 4). On the other hand, the EDSV genome was also detected in the antiEDSV negative sera (Fig. 3, lanes 6, 8, 10 and 11). This result can be explained by higher sensitivity of PCR than that of HI-test. It is also possible that the antiEDSV negative turkeys were still infected by the EDSV, but 


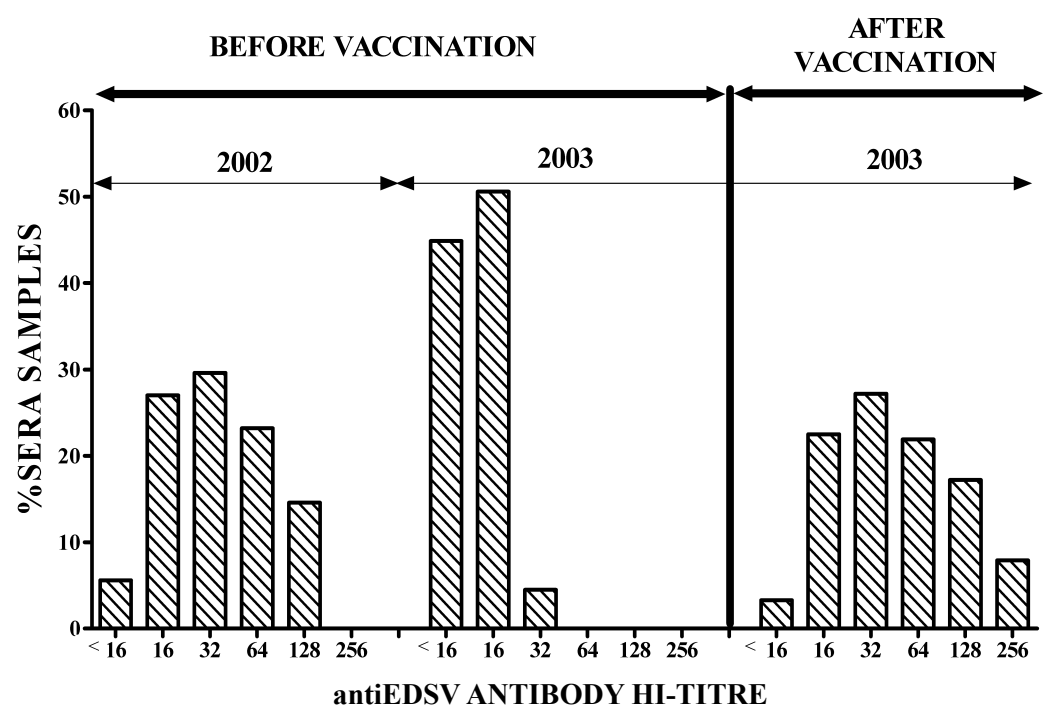

Fig. 2. HI-titres of antiEDSV antibodies in turkey sera prior to and after vaccination against EDSV

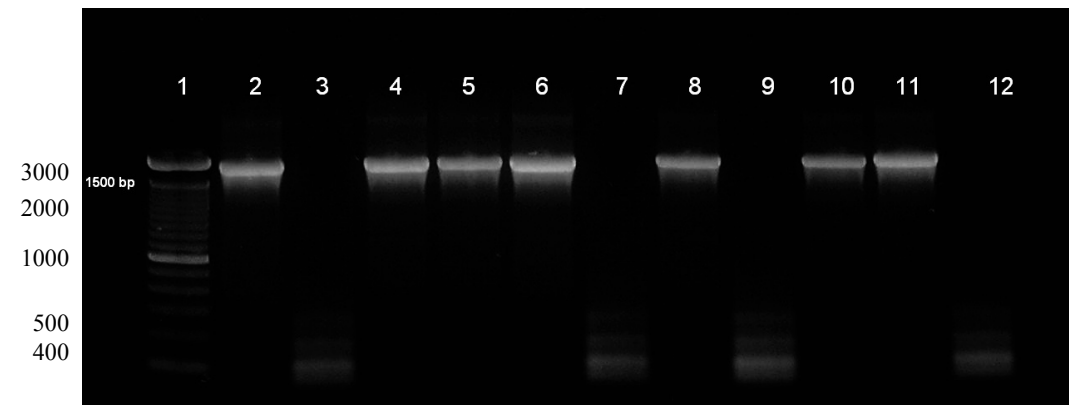

Fig. 3. Electrophoresis of PCR products obtained by amplification of EDSV DNA in turkey sera. Lane 1, $100 \mathrm{bp}$ DNA ladder. Lane 2, IB + ND + EDS commercially available vaccine (Nobilis, Intervet, UK). Lane 3, negative control. Lane 4, antiEDSV positive serum sample of a 27-week-old breeder vaccinated twice against EDSV. Lane 5 , antiEDSV positive serum sample of a 36 -week-old breeder taken in the week $5^{\text {th }}$ of laying in the period of egg production decline. Lanes 6 - 12, randomly chosen antiEDSV negative sera samples collected before turkey vaccination against EDSV.

there was not enough time for the development of measurable levels of specific antibodies.

The antiNDV antibodies were detected in more than $95 \%$ of a total of 195 analysed sera collected prior to and after the vaccination against the EDSV. The antibody HI-titres varied between 16 and 128. The presence of antiNDV antibodies in almost all of analysed sera can be explained as a consequence of a systematically performed turkey vaccination against the NDV.

All analysed sera, collected prior to and after the vaccination against the EDSV, were negative to antibodies against AIV (197 samples), MS (192 samples) and MG (192 samples).

A total of 433 sera were analysed for the presence of the antiAPV antibodies. The ELISA tests showed that 72.1 and $45.5 \%$ of the sera analysed were antiAPV positive prior to and after the vaccination against the EDSV, respectively. The ELISA titres of the antiAPV positive sera varied from 940 to 11400 . In some of the sera samples, both the antibodies 
against the EDSV and the APV were found simultaneously. The antibodies against the APV were detected in $74.4 \%$ of the antiEDSV positive sera prior to the vaccination against the EDSV. After the vaccination, $43.3 \%$ of the sera positive to the antiEDSV, were also positive to the antiAPV. According to these results, the decrease of the egg production and quality might be influenced by the APV infection. On the other hand, the APV infection was permanently present in turkey flocks prior to 2002 and no abnormalities in the egg production were detected during this period. After the vaccination against the EDSV, the egg quality and the production reached the normal values (Fig. 1, 2003b). The levels of the antiAPV antibodies in the breeder sera collected during this laying period were still high. These results and the absence of the AIV, MS and MG infections suggest the possibility that the egg production prior to the vaccination against the EDSV was influenced solely by a naturally-occurring infection. The potential source of the outbreak of the EDS in turkeys could be a horizontal spread of the infection from the non-vaccinated chickens in the neighbourhood of the turkey farms. The EDS, recorded in the turkey flocks not earlier than 2002 , is permanently present in the domestic chickens in Croatia. A systematic vaccination by an inactivated vaccine prior to the laying period (Biđin et al. 1997) is applied for the prevention of the infection in the breeding and commercial egg producer chicken farms but not in the small back-yard flocks.

In the presented examination we showed that after the vaccination programme was introduced, the egg quality and the production reached normal values. This data, together with the serological and PCR analyses of the samples collected under the field conditions proved the existence of a naturally-occurring EDSV turkey infection.

Presented results provide a background for further investigation of the possible new EDSV outbreaks in other turkey farms. Further research will be completed with field virus isolation and characterization.

\section{Přirozený výskyt viru syndromu poklesu snášky krůt}

Počátkem roku 2002 byly v krůtích hejnech v Chorvatsku zaznamenány snížená kvalita vajec, produkce, fertility a líhnivosti bez vážných klinických příznaků nemoci. Předpokládalo se, že jedním z etiologických agens syndromu poklesu snášky, odpovědných za abnormality v produkci vajec, by mohl být virus syndromu poklesu snášky. Systematický monitoring sér, s využitím hemaglutinačně inhibičního testu, prokázal přítomnost protilátek proti viru syndromu poklesu snášky u 94,4 a 55,1\% u sér vyšetřovaných v letech 2002 a 2003. Hemaglutinačně inhibiční titry se pohybovaly v rozmezí $16-128$. Séra byla náhodně odebírána od 11- až 46týdenních krůt z postižených hejn. Sérologický průkaz infekce virem syndromu poklesu snášky byl potvrzen detekcí přítomnosti genomu viru v séru krůt pomocí PCR (polymerázové řetězové reakce). Vakcinace 18 až 25 týdenních krůt proti viru syndromu poklesu snášky bylo započato v březnu roku 2003. Od té doby se produkce krocanů hybridní linie Nikolas vrátila na původní výši nebo se dokonce zvýšila. Př́ítomnost protilátek proti viru syndromu poklesu snášky (hemaglutinačně inhibiční titry mezi 16 - 256) byla zjištěna u $96,7 \%$ z analyzovaných sér.

\section{Acknowledgement}

This research was supported by grants Nos. 053-0531863-1856 and 098-0982929-2524 from the Ministry of Science, Education and Sports, Republic of Croatia.

\section{References}

ADAIR BM, McFERRAN JB, CONNOR TJ, McNULTY MS, McKILLOP ER 1979: Biological and physical properties of a virus (strain 127) associated with egg drop syndrome 1976. Avian Pathol 8: 249-264

ALLAN WH, GOUGH RE 1974: A standard hemagglutination inhibition test for Newcastle disease. 1. A comparison of macro and micro method. Vet Rec 95: 120-123 
BARTHA A, MÉSZÁROS J 1984: Experimental infection of laying hens with an adenovirus isolated from ducks showing EDS symptoms. Acta Vet Hung 33: 125-127

BENKÖ M, HARRACH B, RUSSELL WC, ADAIR BM, ÁDÁM É, de JONG JC, HESS M, JOHNSON M, KAJON A., KIDD AH, LEHMKUHL HD, LI QG, MAUTNER V, PRING-AKERBLOM P, WADELL G 2005: Family Adenoviridae. In: Virus Taxonomy. Classification and Nomenclature of Viruses. The $8^{\text {th }}$ Report of the International Committee on Taxonomy of Viruses. (FAUQUET CM, MAYO MA, MANILOFF J, DESSELBERGER U, BALL LA - Eds.). Elsevier/Academic Press, London, pp. 213-228

BIĐIN Z, ČAJAVEC S, SLADIĆ D, ERGOTIĆ N, CIZELJ A, POKRIĆ B 1997: Protection of broiler breeders by an inactivated combined water-in-oil-in-water viral vaccine. Acta Vet Hung 45: 25-34

BRUGH M, BEARD CW, VILLEGAS P 1984: Experimental infection of laying chickens with adenovirus 127 and with a related virus isolated from ducks. Avian Dis 28: 168-178

DÁN A, RUZSICS Z, RUSSELL WC, BENKÖ M, HARRACH B 1998: Analysis of the hexon gene sequence of bovine adenovirus type 4 provides further support for a new adenovirus genus (Atadenovirus). J Gen Virol 79: $1453-1460$

DAS BB, PRADHAN HK 1992: Outbreaks of egg drop syndrome due to EDS-76 virus in quail (Coturnix coturnix japonica). Vet Rec 131: 264-265

DUROJAIYE OA, AHMED AS, ADENE DF 1992: Egg drop syndrome ' 76 in poultry and other avian species in Nigeria. Rev Elev Méd Vét Pay Trop 44: 37-38

GULKA CM, PIELA TH, YATES VJ, BAGSHAW C 1984: Evidence of exposure of waterfowl and other aquatic birds to the hemagglutinating duck adenovirus identical to EDS 76 virus. J Wildlife Dis 20: 1-5

HESS M, BLOCKER H, BRANDT P 1997: The complete nucleotide sequence of the egg drop syndrome virus, an intermediate between mastadenoviruses and aviadenoviruses. Virology 238: 145-156

HARRACH B, MEEHAN BM, BENKÖ M, ADAIR BM, TODD D 1997: Close phylogenetic relationship between egg drop syndrome virus, bovine adenovirus serotype 7, and ovine adenovirus strain 287 . Virology 229: $302-306$

IVANICS É, PALYA V, GLÁVITS R, DÁN Á, PÁLFI V, RÉVÉSZ T, BENKÖ M 2001: The role of egg drop syndrome virus in acute respiratory disease of goslings. Avian Pathol 30: 201-208

KALETA EF, REDMANN T, BONNER B, BECK I, JAGER S 2003: Egg drop syndrome 1976, host range, prevalence and prevention. Wien Tierarztl Monatschr 90: 182-191

MALKINSON M, WEISMAN Y 1980: Serological survey for the prevalence of antibodies to egg drop syndrome 1976 virus in domesticated and wild birds in Israel. Avian Pathol 7: 483-490

McFERRAN JB, ADAIR BM 2003: Egg drop syndrome. In: SAIF YM, BARNES HJ, GLISSON JR, FADLY AM, MCDOUGALD LR, SWAYNE DE (Eds.): Diseases of Poultry, $11^{\text {th }}$ ed., State Press, Iowa, pp. 227-237

PARSONS DG, BRACEWELL CD, PARSONS G 1980: Experimental infection of turkeys with egg drop syndrome 1976 virus and studies on the application of the haemagglutination inhibition test. Res Vet Sci 29: 89-92

RAUE R, HESS M 1998: Hexon based PCRs combined with restriction enzyme analysis for rapid detection and differentiation of fowl adenoviruses and egg drop syndrome virus. J Virol Meth 73: 211-217

SCHLÖR GM 1980: Frequency of antibody to adenovirus 127 in domestic ducks and wild waterfowl. Avian Dis 24: $91-98$

Van ECK JHH, DAVELAAR FG, Van den HEUVEL-PLESMAN TAM, Van KOL N, KOUWNHOVEN B, GULDIE FHM 1976: Dropped egg production, soft shelled and shell-less eggs associated with appearance of precipitins to adenovirus in flocks of laying fowl. Avian Pathol 5: 261-272

ZANELLA A, Di DONATO A, NIGRELLI A, POLI G 1980: Egg drop syndrome (EDS'76), Ethiopatogenesis, epidemiology, immunology and control of the disease. Clin Vet 103: 459-469

ZSAK I, SZELELY A, KISARY J 1982: Experimental infection of young and laying geese with egg drop syndrome 1976 adenovirus strain B8/78. Avian Pathol 11: 555-562 